
\title{
3 Research Square \\ Childhood stunting and associated factors among irrigation and non-irrigation user Northwest, Ethiopia: a comparative cross-sectional study
}

\section{Balew Sema}

Bahir Dar University

Muluken Azage ( $\square$ mulukenag@yahoo.com )

Bahir Dar University College of Medical and Health Sciences https://orcid.org/0000-0003-3222-0158

\section{Mulat Tirfie}

Bahir Dar University College of Medical and Health Sciences

\section{Research}

Keywords: Childhood stunting, Irrigation and Non-irrigation user, Mecha District, North west, Ethiopia

Posted Date: October 30th, 2020

DOl: https://doi.org/10.21203/rs.3.rs-66889/v2

License: (c) (i) This work is licensed under a Creative Commons Attribution 4.0 International License.

Read Full License

Version of Record: A version of this preprint was published at Italian Journal of Pediatrics on April 26th, 2021. See the published version at https://doi.org/10.1186/s13052-021-01048-x. 


\section{Abstract}

Background: Stunting is a critical public health problem of developing countries like Ethiopia. Different interventions like irrigation activity have been carried out by the government of Ethiopia to improve the nutritional status of the community. However, there is scanty of data on childhood stunting and its associated factors between irrigation user and non-irrigation user.

Objective: To assess the magnitude of childhood stunting and its associated factors between irrigation and non-irrigation user in North Mecha District, Northwest Ethiopia. Methods: A community-based comparative cross-sectional study design was employed from October to November 2019. A systematic sampling was used to draw mothers with children age 6-59 months (582 irrigated and 582 non- irrigated household users). Data were collected using questionnaire and anthropometric measurement tools. Multivariable logistic regression was used to identify the predictors of stunting. Adjusted odds ratios with $95 \% \mathrm{Cl}$ were used to determine the degree of association between independent and outcome variable. Ap-value $<0.05$ was used as cutoff point to declare statistically significant variables with the outcome variable.

Results: The prevalence of childhood stunting (6-59 months) among irrigation users [32.8\% at 95\% $\mathrm{Cl}(29-$ $37)]$ was slightly higher than non-usurers $[40.2 \%$ at $95 \% \mathrm{Cl}(36-44)]$. However, the difference did not show significant variation. The odds of childhood stunting were higher among a child from a mother had no antenatal visit, a child whose age was between 12 and 47 months, a child from a mother who did not use water and soap always for washing hands, and a child who had fever.

Conclusion: The prevalence of childhood stunting was high and did not show significant variation between irrigation and non-irrigation users. A child from mother had no antenatal visit, whose age was between 12 and 47 months, a mother who did not use water and soap always for washing hands, and who had fever were factors associated with higher child stunting. Thus, the identified modifiable factors should be strengthened to reduce stunting.

\section{Introduction}

Globally, stunting remains one of the major public health problems among children under five years of age (1) . It is an indicator of malnutrition in early childhood and is strongly associated with numerous short-term and long-term conditions $(2,3)$. It is the best of overall indicator of children's well-being and an accurate reflection of social inequalities. Use of stunting as a direct indicator of nutritional status have shifted focus away from considering a broad set of environmental and social determinants of child growth to a disproportionate emphasis on dietary determinants of linear growth (4). . It is the result of the complex interaction between the food we eat, our overall state of health, and the environment in which we live in $(5,6)$.

The burden of stunting is multidimensional which are related with retarded growth, behavior development, poor school performance, lower working capacity, losses in cognitive function, losses in 
income, decreases productivity, and increased likelihood of chronic disease, if not corrected, it can slow down economic growth and increase poverty levels (7-9). In the past twenty years, 55.5 billion Ethiopian birr (1.51 billion USD) are estimated with the costs associated with child under nutrition, equivalent to $16.5 \%$ of Gross Domestic Product (GDP) (10-12).

In 2019, the prevalence of stunting in Ethiopia was estimated to be $37 \%$ (13). In the same year, the percentage of stunting is higher in Amhara region compared to national figure (41\%), indicating inappropriate child feeding practices in the region (13). Stunting usually increases between age 6 and 23 months, and peaks at age 24- 35 months due to different reasons (13).

Different intervention with national nutrition strategies, nutrition specific and nutrition sensitive intervention activities with focus on improving Infant and Young Child Feeding have been implemented to reduce chronic malnutrition. Increasing agricultural production through irrigation system to meet food security at household level is also one of the strategies to address the basic needs of the community. Studies on prevalence of childhood stunting so far have been conducted in general community $(7,14$, 15), which are either irrigated or non-irrigated users. To the best of our knowledge, there is not specific study of the prevalence of childhood stunting and associated factors among irrigation and non-irrigation users. This study aimed to answer the following research questions: (1) Is the magnitude of childhood stunting differ between irrigation and non-irrigation users? and (2) Which factors do determine the occurrence of childhood stunting in North Mecha District, Amhara Region, Northwest Ethiopia? The findings from this study will help to irrigations users in identify the gap and maximize the potential of irrigation for their health benefits.

\section{Methods}

\section{Study area and period}

The study area is Mecha district which is located at $530 \mathrm{kms}$ in Northwest direction of Addis Ababa, the capital city of Ethiopia, and $35 \mathrm{kms}$ in the Southwest direction of Bahir Dar, capital city of Amhrara National Region State. It is one of the thirteen districts found in West Gojjam Administrative Zone. The district comprises three climatic zone; high land "Dega", mid-altitude "Wena Dega" and lowlands "Kola". The mean annual rainfall ranges from $1,000 \mathrm{~mm}$ to $2,000 \mathrm{~mm}$. The district has 156,027 hectares area, of which 72,178 hectares are used for cultivation and about 1,386 hectares covered by water bodies. The district has 40 Kebeles (Kebele is the lowest administrative unit in Ethiopia) (10 irrigation users and others are non-irrigated). Irrigation users are all households in a Kebele have access to the irrigation system from Koga dam (16). Based on the 2007 national census, the estimated population of the district in 2019, is about 303,208 , of which 150,088 are males and 153,120 are females. The district has 10 health center and 38 health posts and 1 government hospital during the time of the study (17). The district is one of the food surplus areas and the commonest staple foods are maize, millet, teff and barley (16). The study was conducted from October to December in 2019, 


\section{Study design and population}

A community-based comparative cross-sectional study design was employed to assess the prevalence and its associated factors of childhood stunting. All mothers/care-takers with children age 6-59 months in both irrigation users and non-irrigation were source of population in the district. All mothers/care takers with children age 6-59 months in the randomly selected Kebele were study populations.

\section{Sample size determination}

The adequate sample size for this study was determined using two-population proportion formula [n (in each group $\left.)=f(a, \beta)(p 1 q 1+p 2 q 2) /(p 1-p 2)^{2}\right]$ with the following assumptions: $f(a, \beta)=7.84$, when the power $=80 \%$, the level of significance $=5 \%$ and the prevalence of stunting among irrigating (P1) was $10 \%$ and non-irrigated (P2) was $17 \%$ from previous study in Kenya (18), design effect of 1.5 and $5 \%$ of nonresponses rate. Based on the above assumptions, a sample size of $1164 \mathrm{HHs}$ (582 irrigation users and 582 non-irrigation users) was calculated for the study.

\section{Sampling technique and sampling procedure}

First, Kebeles in the district were stratified based on irrigation status (irrigation users and non-irrigation users). Six Kebeles from each stratum were selected randomly and proportion to size allocation was made to determine the required households from each randomly selected Kebeles. Households from randomly selected Kebeles were selected using systematic sampling technique. Sampling interval was determined by dividing the total number of households in each Kebele with the allocated sample size. The schematic sampling procedures was attached as supplementary file (Supplement file 1)

\section{Data collection tools}

Socio-demographic and other data were collecting by using structured questionnaire adapted from different standard questionnaires and literatures. The anthropometric data was collected by using WHO Recommendations for data collection, analysis and reporting on anthropometric indicators in children under 5 years old (19). A vertical or horizontal measuring board reading a maximum of $175 \mathrm{~cm}$ and capable of measuring to $0.1 \mathrm{~cm}$ was used to take the height of a child. The child stands on the measuring board barefoot; have hands hanging loosely with feet parallel to the body, and heels, buttocks, shoulders and back of the head touching the board. The head was held comfortably erect with the lower border of the orbit of the eye being in the same horizontal plane as the external canal of the ear. The headpiece of the measuring board is then pushed gently, crushing the hair and making contact with the top of the head. Height is then read to the nearest $0.1 \mathrm{~cm}$. For those with written evidence, date of birth was obtained from clinic cards, child health cards and immunization status certificates of the children, unless by asking mother/care takers age was determined. 


\section{Operational Definitions}

Irrigation users are all households in a Kebele have access to the irrigation system whereas non-irrigation users refer household which did not have irrigation system. Improved water includes piped water on premises such as piped household water connection located inside the user's dwelling, plot or yard, public taps or standpipes, tube wells or boreholes, protected dug wells, protected springs and rainwater collection. Unimproved drinking water sources include unprotected dug wells, unprotected springs, carts with small tank/drum, tanker trucks, surface water (river, dam, lake, pond, stream, canal, irrigation channels) and bottled water. Improved sanitation facilities are used by only one family and can include toilets connected to sewers or septic systems, water-based toilets that flush into pits, simple pit latrines with slabs, and ventilated improved pit latrines. Unimproved sanitation facilities include those shared by more than one household, flush/pour flush to elsewhere in the environment without proper waste water treatment, the use of buckets, hanging latrines, or pit latrines without slab coverings and open defecation

\section{Data quality assurance}

Pretest of the questionnaire, training and calipering of the weigh scale were done to assure data quality. The questionnaire was developed from previous literature and field pre-tested on five percent of sample size was done. Before the actual data collection, training was given for data collectors and supervisors. During the training, the trainers give instructions on the questions to be asked, their meaning, how to ask them, and how to record the answers. Data collectors and supervisors were also trained using role play practices. The equipment that was used to measure the anthropometric variables was calibrated between five respondents for actual data collection by using a known weight material. At the end of every data collection day, each questionnaire was examined for its completeness and consistency by the principal investigator and pertinent feedback was given to the data collectors and supervisors. All completed Epi (survey solution software) collected data entered questionnaire was conducted daily and Examined by principal investigator.

\section{Data processing and analysis}

Data were collected using Epi collect survey solution software and directly downloaded to Excel, exported to SPSS version 23. Data was cleaned before data analysis. The anthropometric data was exported to WHO Anthro plus software to computed individual level of nutritional status. Frequencies, proportions and chi-square were computed for description of the study population in relation to socio-demographic and other variables. Bivariate and multivariable analysis logistic regressions were done to determine the association between stunting and explanatory variables. Those independent variables whose $\mathrm{p}$-value less than 0.2 at the bivariable regression were included in a multivariable logistic regression model. Adjusted odds ratio with $95 \% \mathrm{Cl}$ was calculated to measure the degree of association between stunting and 
explanatory variables. A-p-value $<0.05$ was used as cutoff point to declared statistically significant variables with the outcome variable.

\section{Ethical consideration}

The study was approved by the Ethics Review Board of College of Medicine and Health Sciences Board (CMHS/IRB 03-008), Bahir Dar University. A support letter from the University was written to the Amhara Regional Health Bureau. Permission and a letter of support for the study were then obtained from the

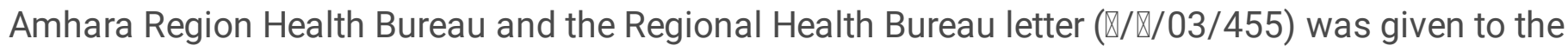
district health office to commence the study. Information related ethical issue was given for mothers/caretakers (since most of them are farmers and could not able to read and write) by reading its content attached together in the first part of the questionnaire. Each study participant was briefed on the objective of the study, and informed about the right to refuse to participate in the study or to discontinue at any time. Participants were also informed that all data was confidential and personal identifiers were not registered. Interview was conducted after the parents and/or legal guardians of the child participants on their behalf provided verbal consent to participate in the study.

\section{Results}

\section{Socio-demographic and economic status of participants}

Of 1164 Households (HHs) randomly selected to participate in the study, $582 \mathrm{HHs}$ from each irrigation and non-irrigation users were included in the analysis. Sixty eight percent of the respondent were found at greater and equal to 30 years, $71.0 \%$ from irrigated and $65 \%$ from non-irrigated users. Seventy-six from $(76.3 \%)$ irrigation users and $72.2 \%$ from non-irrigation users had greater than four family members. Above eighty percent of mothers from irrigation users (83.0\%) and non-irrigation (80.9\%) were unable to read and write (Table 1 ).

Forty-one percent of mothers from irrigation users and $36.4 \%$ of mothers from non-irrigation users had greater than three antenatal care (ANC) visit during their pregnancy. Eighty-three percent of mothers from irrigation users and $88.0 \%$ of mothers from non-irrigation users had no postnatal care (PNC) visit after birth. Regarding health institution location, $24.4 \%$ of mothers from irrigation users and $64.4 \%$ of mothers from non-irrigation users took one hour and above (Table 1).

Two-third of $\mathrm{HHs}(75.3 \%)$ from irrigation users and $73.9 \%$ of $\mathrm{HHs}$ from non-irrigation users had improved water source. Sixty-eight of $\mathrm{HHs}(67.7 \%)$ from irrigation users and $38.1 \%$ of $\mathrm{HHs}$ from non-irrigation users had improved latrine. Regarding hand washing habits, thirteen percent of mothers from irrigation users and $5.2 \%$ of mothers from non-irrigation users use always soap and water (Table 1 ).

Table 1: Socio-demographic and economic status of respondents in irrigation and non-irrigation users in Mecha district, Northwest Ethiopia, 2019 


\begin{tabular}{|c|c|c|c|c|c|c|}
\hline \multirow[t]{2}{*}{ Characteristics } & \multicolumn{2}{|l|}{ Irrigated } & \multicolumn{2}{|c|}{ Non-irrigated } & \multirow[t]{2}{*}{ Total } & \multirow{2}{*}{$\begin{array}{l}\text { Chi-square ( } p \text { - } \\
\text { value) }\end{array}$} \\
\hline & Frequency & percent & Frequency & percent & & \\
\hline \multicolumn{7}{|l|}{ Mother's age } \\
\hline$<20$ years & 16 & 2.7 & 17 & 2.9 & $\begin{array}{l}33 \\
(2.8)\end{array}$ & $4.70(0.095)$ \\
\hline 20-29 years & 153 & 26.3 & 186 & 32.0 & $\begin{array}{l}339 \\
(29.1)\end{array}$ & \\
\hline$\geq 30$ years & 413 & 71.0 & 379 & 65.1 & $\begin{array}{l}792 \\
(68.0)\end{array}$ & \\
\hline \multicolumn{7}{|l|}{ Family size } \\
\hline$\leq 4$ members & 138 & 23.7 & 186 & 32.0 & $\begin{array}{l}324 \\
(27.8)\end{array}$ & $9.85(0.002)$ \\
\hline$>4$ members & 444 & 76.3 & 396 & 68.0 & $\begin{array}{l}840 \\
(72.2)\end{array}$ & \\
\hline \multicolumn{7}{|l|}{ Mother education } \\
\hline $\begin{array}{l}\text { Unable to read and } \\
\text { write }\end{array}$ & 483 & 83.0 & 471 & 80.9 & $\begin{array}{l}954 \\
(82.0)\end{array}$ & $0.84(0.36)$ \\
\hline $\begin{array}{l}\text { Able to read and } \\
\text { write }\end{array}$ & 99 & 17.0 & 111 & 19.1 & $\begin{array}{l}210 \\
(18.0)\end{array}$ & \\
\hline \multicolumn{7}{|l|}{ Antenatal care visit } \\
\hline No visit & 6 & 1.0 & 40 & 6.9 & $\begin{array}{l}46 \\
(4.0)\end{array}$ & $27.26(<0.001)$ \\
\hline $1-3$ visits & 333 & 57.2 & 330 & 56.7 & $\begin{array}{l}663 \\
(57.0)\end{array}$ & \\
\hline$>3$ visits & 243 & 41.8 & 212 & 36.4 & $\begin{array}{l}455 \\
(39.1)\end{array}$ & \\
\hline \multicolumn{7}{|l|}{ Frequency of PNC } \\
\hline No visit & 484 & 83.2 & 512 & 88.0 & $\begin{array}{l}996 \\
(85.6)\end{array}$ & $13.5(0.001)$ \\
\hline $1-2$ visit & 83 & 14.3 & 46 & 7.9 & $\begin{array}{l}129 \\
(11.1)\end{array}$ & \\
\hline$>3$ visit & 15 & 2.6 & 24 & 4.1 & $\begin{array}{l}39 \\
(3.4)\end{array}$ & \\
\hline \multicolumn{7}{|l|}{$\begin{array}{l}\text { Time taken to reach } \\
\text { the health facility }\end{array}$} \\
\hline$<1$ hour & 442 & 75.9 & 207 & 35.6 & 649 & $192.32(<0.001)$ \\
\hline
\end{tabular}




$\begin{array}{llllll}\geq 1 \text { hour } & 140 & 24.1 & 375 & 64.4 & 515\end{array}$

\section{Drinking water} source

\begin{tabular}{|lccccll} 
Improved source & 438 & 75.3 & 430 & 73.9 & $\begin{array}{l}868 \\
(74.6)\end{array}$ & $0.29(0.590)$ \\
\hline Unimproved source & 144 & 24.7 & 152 & 26.1 & $\begin{array}{l}296 \\
(25.4)\end{array}$ &
\end{tabular}

\section{Latrine facility}

Improved latrine

394

67.7

222

38.1

616

(52.9)

Unimproved latrine $\quad 188$

32.3

360

61.9

548

(47.1)

\section{Ways of Hand washing habits}

$\begin{array}{lccccll}\text { Only with water } & 26 & 4.5 & 208 & 35.7 & \begin{array}{l}234 \\ (20.1)\end{array} & 184.34(<0.001) \\ \begin{array}{l}\text { Sometime with } \\ \text { soap and water }\end{array} & 479 & 82.3 & 344 & 59.1 & \begin{array}{l}823 \\ (70.7)\end{array} \\ \begin{array}{l}\text { Always with soap } \\ \text { and water }\end{array} & 77 & 13.2 & 30 & 5.2 & \begin{array}{l}107 \\ (9.2)\end{array}\end{array}$

\section{Prevalence of stunting and other characteristics}

The overall prevalence of stunting was $36.5 \%$ (95\% Cl 33.8\% to $39.3 \%)$ and did not show significant variation between irrigated $32.8 \%(95 \% \mathrm{Cl} 29.1 \%$ to $36.7 \%)$ and non-irrigated users $40.2 \%(95 \% \mathrm{Cl} 36.3 \%$ to $44.2 \%)$. Sixty-three percent (63.4\%) of children from irrigation users and $57.9 \%$ of children from nonirrigation users had initiation breast feed within one hour. Half of children $(50.2 \%)$ from irrigation users and $54.0 \%$ of mothers from non-irrigation users were male by sex (Table 2 ).

Nearly one fourth of children (24.6\%) from irrigation users and $30.1 \%$ of mothers from non-irrigation users were between 24 and 35 months.. Eighteen percent of children (24.6\%) from irrigation users and $22.7 \%$ of mothers from non-irrigation users had fever in the past two weeks before preceding the survey (Table 2).

Table 2: Prevalence of stunting and diarrhea, and Height for Age among irrigation and non-irrigation users in Mecha district, Northwest Ethiopia, 2019 


\begin{tabular}{|c|c|c|c|c|c|c|}
\hline \multirow{2}{*}{ Characteristics } & \multicolumn{2}{|c|}{ Irrigated } & \multicolumn{2}{|c|}{ Non-irrigated } & \multirow[t]{2}{*}{ Total } & \multirow{2}{*}{$\begin{array}{l}\text { Chi-square ( } p \text { - } \\
\text { value) }\end{array}$} \\
\hline & Fre. & percent & Fre. & percent & & \\
\hline \multicolumn{7}{|c|}{ Child Stunting status } \\
\hline Stunted & 191 & 32.8 & 234 & 40.2 & $\begin{array}{l}425 \\
(36.5)\end{array}$ & $6.85(0.009)$ \\
\hline Not stunted & 391 & 67.2 & 348 & 59.8 & $\begin{array}{l}739 \\
(63.5)\end{array}$ & \\
\hline \multicolumn{7}{|c|}{ Initiation of Breast-feeding } \\
\hline Within 1 hour & 369 & 63.4 & 337 & 57.9 & $\begin{array}{l}706 \\
(60.7)\end{array}$ & $3.69(0.05)$ \\
\hline More than 1 hour & 213 & 36.6 & 245 & 42.1 & $\begin{array}{l}458 \\
(39.3)\end{array}$ & \\
\hline \multicolumn{7}{|c|}{$\begin{array}{l}\text { Age start complementary } \\
\text { feeding }\end{array}$} \\
\hline$\geq 6$ months & 518 & 89.0 & 430 & 73.9 & $\begin{array}{l}948 \\
(81.4)\end{array}$ & $44.02(<0.001)$ \\
\hline$<6$ months & 64 & 11.0 & 152 & 26.1 & $\begin{array}{l}216 \\
(18.6)\end{array}$ & \\
\hline \multicolumn{7}{|l|}{ Child sex } \\
\hline Male & 292 & 50.2 & 314 & 54.0 & $\begin{array}{l}606 \\
(52.1)\end{array}$ & $1.67(0.197)$ \\
\hline Female & 290 & 49.8 & 268 & 46.0 & $\begin{array}{l}558 \\
(47.9)\end{array}$ & \\
\hline \multicolumn{7}{|l|}{ Child age } \\
\hline$<12$ months & 33 & 5.7 & 86 & 14.8 & $\begin{array}{l}119 \\
(10.2)\end{array}$ & $65.66(<0.001)$ \\
\hline $12-23$ months & 81 & 13.9 & 119 & 20.4 & $\begin{array}{l}200 \\
(17.2)\end{array}$ & \\
\hline 24-35 months & 143 & 24.6 & 175 & 30.1 & $\begin{array}{l}318 \\
(27.3)\end{array}$ & \\
\hline $36-47$ months & 166 & 28.5 & 119 & 20.4 & $\begin{array}{l}285 \\
(24.5)\end{array}$ & \\
\hline $48-60$ months & 159 & 27.3 & 83 & 14.3 & $\begin{array}{l}242 \\
(20.8)\end{array}$ & \\
\hline \multicolumn{7}{|l|}{ Had diarrhea } \\
\hline Yes & 99 & 17.0 & 119 & 20.4 & 218 & $2.26(0.133)$ \\
\hline
\end{tabular}


$463 \quad 79.6$

\section{Had Fever}

Yes

No
105

477
18.0

132

22.7

237

(20.4)

$\begin{array}{lll}450 & 77.3 \quad 927\end{array}$

$\begin{array}{llll}82.0 & 450 & 77.3 & 927 \\ & & & (79.6)\end{array}$

\section{Factors associated with stunting in irrigation and non- irrigation users}

Based on the results of the multivariable logistic regression model, the odds of stunting are associated with ANC visit. The odds of child stunting from a mother that did not visit ANC were 2.61 [AOR $=2.61$; $95 \% \mathrm{Cl}: 1.33-5.12]$ higher compared to a child from a mother who had more than three visits. The odds of child stunting whose age between 12 and 23 months, 24 and 35 months, and 36 and 47 months were 2.60 times [AOR $=2.60 ; 95 \% \mathrm{Cl}: 1.51-4.48], 2.92$ times [AOR $=2.92 ; 95 \% \mathrm{Cl}: 1.74-4.89$ ], and 3.55 times [AOR $=3.55 ; 95 \% \mathrm{Cl}: 2.09-6.01]$, higher compared to a child whose age less than 12 months respectively. The odds of child stunting from a respondent who washed their hands with water only and sometimes with soap and water were 2.27 times [AOR $=2.27 . ; 95 \% \mathrm{Cl}: 1.25-4.22]$ and 1.77 times [AOR = 1.77.; $95 \% \mathrm{Cl}: 1.06$ - 2.97] higher compared to a respondents who always practicing hand washing with soap and water. The odds of stunting in a child who had fever were 1.77 times [AOR $=1.77 ; 95 \% \mathrm{Cl}$ : 1.29 2.43] higher compared to a child who had no fever for the last two weeks before preceding the study (Table 3).

Table 3: Multivariable Logistic Regression Analysis of factors affecting childhood stunting in irrigation and non-irrigation users in Mecha district, Northwest Ethiopia, 2019 


\begin{tabular}{|c|c|c|c|c|}
\hline \multirow[b]{2}{*}{ Characteristics } & \multicolumn{2}{|c|}{ Stunting } & \multirow[b]{2}{*}{ COR $(95 \% \mathrm{Cl})$} & \multirow[b]{2}{*}{ AOR $(95 \% \mathrm{Cl})$} \\
\hline & Yes & No & & \\
\hline \multicolumn{5}{|l|}{ Irrigation status } \\
\hline Irrigated & 191 & 391 & 1.00 & \\
\hline Non-irrigated & 234 & 348 & $1.37(1.08-1.74)^{\star \star}$ & \\
\hline \multicolumn{5}{|l|}{ Child Sex } \\
\hline Male & 227 & 379 & $1.09(0.86-1.38)$ & \\
\hline Female & 198 & 360 & 1.00 & \\
\hline \multicolumn{5}{|l|}{ Women's age } \\
\hline$<20$ years & 10 & 23 & 1.00 & \\
\hline $20-29$ years & 118 & 221 & $1.23(0.57-2.67)$ & \\
\hline$\geq 30$ years & 297 & 495 & $1.38(0.65-2.94)$ & \\
\hline \multicolumn{5}{|l|}{ Family size } \\
\hline$\leq 4$ members & 111 & 213 & 1.00 & \\
\hline$>4$ members & 314 & 526 & $1.15(0.87-1.50)$ & \\
\hline \multicolumn{5}{|l|}{ Women education } \\
\hline Unable to read and write & 365 & 589 & $1.55(1.12-2.15)^{\star \star}$ & \\
\hline Able to read and write & 60 & 150 & 1.00 & \\
\hline \multicolumn{5}{|l|}{ Initiation of Breast-feeding } \\
\hline Within 1 hour & 262 & 444 & $1.06(0.84-1.36)$ & \\
\hline More than 1 hour & 163 & 295 & 1.00 & \\
\hline \multicolumn{5}{|c|}{ Age start complementary feeding } \\
\hline$\geq 6$ months & 338 & 610 & 1.00 & \\
\hline$<6$ months & 87 & 129 & $1.22(0.90-1.65)$ & \\
\hline \multicolumn{5}{|l|}{ Antenatal care visit } \\
\hline No visit & 29 & 17 & 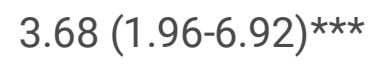 & $2.61(1.33-5.12)^{\star \star}$ \\
\hline $1-3$ visits & 144 & 311 & $1.32(1.03-1.70)^{*}$ & $1.21(0.93-1.57)$ \\
\hline
\end{tabular}




\begin{tabular}{|c|c|c|c|c|}
\hline$>3$ visits & 252 & 411 & 1.00 & 1.00 \\
\hline \multicolumn{5}{|l|}{ Frequency of PNC } \\
\hline No visit & 376 & 620 & $1.54(0.76-3.13)$ & \\
\hline $1-2$ visit & 38 & 91 & $1.07(0.48-2.35)$ & \\
\hline$>3$ visit & 11 & 28 & 1.00 & \\
\hline \multicolumn{5}{|l|}{ Heath facility far from home } \\
\hline$<1$ hour & 214 & 435 & 1.00 & \\
\hline$>=1$ hour & 211 & 304 & $1.41(1.10-1.79)^{\star \star}$ & \\
\hline \multicolumn{5}{|l|}{ Child sex } \\
\hline Male & 227 & 379 & 1.00 & \\
\hline Female & 198 & 360 & $0.92(0.72-1.17)$ & \\
\hline \multicolumn{5}{|l|}{ Child age } \\
\hline$<12$ months & 24 & 95 & 1.00 & 1.00 \\
\hline $12-23$ months & 77 & 123 & $2.48(1.46-4.21)^{\star \star}$ & $2.60(1.51-4.48)^{\star \star}$ \\
\hline 24-35 months & 132 & 186 & $2.81(1.70-4.63)^{\star \star \star}$ & $2.92(1.74-4.89)^{\star \star \star}$ \\
\hline $36-47$ months & 131 & 154 & $3.38(2.03-5.58)^{\star \star \star}$ & $3.55(2.09-6.01)^{\star \star \star}$ \\
\hline $48-60$ months & 61 & 181 & $1.33(0.78-2.27)$ & $1.39(0.80-2.42)$ \\
\hline \multicolumn{5}{|l|}{ Drinking water source } \\
\hline Improved source & 311 & 557 & 1.00 & \\
\hline Unimproved source & 114 & 182 & $1.12(0.85-1.47)$ & \\
\hline \multicolumn{5}{|l|}{ Latrine facility } \\
\hline Improved source & 211 & 405 & 1.00 & \\
\hline Unimproved source & 214 & 334 & $1.23(0.97-1.56)$ & \\
\hline \multicolumn{5}{|l|}{ Ways of Hand washing habits } \\
\hline Only with water & 105 & 129 & $3.14(1.84-5.37)^{\star \star \star}$ & $2.27(1.25-4.11)^{\star \star}$ \\
\hline Sometime with soap and water & 298 & 525 & $2.19(1.34-3.58)^{\star \star}$ & $1.77(1.06-2.97)^{\star}$ \\
\hline Always with soap and water & 22 & 85 & 1.00 & 1.00 \\
\hline
\end{tabular}




\begin{tabular}{|lllll|}
\hline Yes & 94 & 124 & $1.41(1.04-1.90)^{*}$ & \\
\hline No & 331 & 615 & 1.00 & \\
\hline Had Fever & & & & $1.77(1.29-2.43)^{\star \star * *}$ \\
\hline Yes & 113 & 124 & $1.80(1.35-2.40)^{\star \star *}$ & 1.00 \\
\hline No & 312 & 615 & 1.00 & \\
\hline
\end{tabular}

${ }^{*} \mathrm{P}<0.001,{ }^{* *} \mathrm{P}<0.01,{ }^{* \star *} \mathrm{p}<0.05$

\section{Discussion}

The study revealed that the overall prevalence of stunting is $36.5 \%(95 \% \mathrm{Cl} 33.8$ to $39.3 \%)$ among the participating HHs. This finding is consistent with the mini DHS result in Amhara Region (42\%) (20), East and West Gojjam zone of Amhara region (37.5\%) (21). However, this result is lower than the prevalence reported from the previous study conducted in West Gojjam (43.5\%) (22) and in Awi Zone (50\%), Amhara region (23). According to the WHO's classification, the prevalence of stunting in the study area is high ( $>40 \%$ is very high, 30 to $39 \%$ is high, 20 to $29 \%$ is medium and $<20 \%$ is classified as a low prevalence(24). The variation in the prevalence of stunting in different studies may be attributed to a broad range of interrelated factors such as environmental or geographical factors (e.g. population density, rainfall and temperature variation and disease environment), socio-cultural differences in relation to child feeding and care practices, maternal under nutrition, $\mathrm{HH}$ food insecurity, economic growth and maternal education $(21,25-27)$.

This study found that significant variation of child stunting did not observe between irrigated and nonirrigated user. The finding of the study is inconsistent with previous studies, which showed that irrigation is associated with a reduced risk of stunting $(28,29)$. Studies revealed that irrigation schemes can ensure household food security $(28,29)$. Although food security may be a necessary prerequisite for good nutrition outcomes, it is insufficient by its own to improve nutritional outcomes (30). The nutritional status of children can be addressed by adopting a multi-sectorial approach $(31,32)$ and determined by mother knowledge on child nutrition practice, maternal nutritional status, intra household food allocation and utilization practices, and access to health services and healthy environmental conditions. For example, the head of the family gets first priority in eating while mothers and children get a smaller share of the family's food relative to their nutritional need due to hierarchical position with intra-family food distribution (33). A study also revealed that some farmers using irrigation schemes engaged in marketoriented crops (34) which might not be necessary improve the nutritional status of children. Thus, further study is recommended to clearly understand the root cause of child malnutrition in the study area community.

Children aged $>12$ months were found a significant association with child stunting compared to infants of less than one year in this study which is consistent with other studies $(35,36)$. The extent of stunting 
usually common after age of 12 months due to several reasons. The children usually terminate breastfeeding after age of 12 months, do not get adequate diet and proper care, and expose to pathogens due to poor environment facilities at household level such as house with poor hygiene, unsafe water supply and sanitation (37). Literature indicates improved behavioral practices such as hand washing before eating early on are important to consider along with other factors closely associated with the age of the child (35).

In this study, children whose mother had no ANC visit increase the odds of child stunting compared to multiple contacts during ANC visits which is consistent with previous studies $(38,39)$. Mothers who made frequent and regular contacts with health care provider get a chance for interactive health education sessions. Thus, multiple contacts during ANC enhance mother knowledge of appropriate feeding for their infants after delivery, including breastfeeding and feeding a diverse diet, and practice preventive and curative child care activities such as timely seeking of health care services, which in turn can have a positive effect on children's nutritional status.

The result of this study indicated that male children were slightly more stunted than female children (53\% and $47 \%$, respectively) but not at a level of statistical significance, which is consistent with other findings $(40,41)$. There are studies which show males are at higher risk for stunting (42-45) whereas another study found that females are at higher risk for stunting (46). These sex-related differences may require further study to understand the relationship between child sex and nutrition.

In this study, improved water supply and sanitation did not show a significant reduction in child stunting, however, hand washing practice with soap was one of the significant factors associated with a reduction in child stunting. Inconsistent findings on benefits of improved water supply and sanitation and hygiene in child stunting reduction were reported $(35,47,48)$. Some studies showed a strong association between the level of environmental WASH (Water, Sanitation and Hygiene) and child linear growth $(37,49)$. The concept of a clean play and infant feeding area as an additional component of early child development programs along with WASH is one of the recommended strategies to reduce child stunting $(35,37,49-51)$. The literature indicates that sanitation and water supply improvements, hand washing with soap, ensuring a clean play and infant feeding environment and food hygiene are all important to interrupt the multiple transmission pathways of fecal-oral pathogens $(37,50)$. Better hygiene practices are essential to prevent diarrhea and other infections among children, which in turn contribute to reducing child stunting.

Previous studies on the association between improved drinking water stunting found inconsistent findings, while other studies have shown that the definition of "improved" does not reliably predict the microbiological safety of the water $(52,53)$. Studies revealed that household access to an improved source of drinking water or piped water was not associated with child stunting $(54,55)$. On the other hand, a study done by Fink et al. using the merged data set of 171 Demographic and Health Surveys found access to improved drinking water was associated with a lower risk of mild or severe stunting (56). There is inconsistent findings of synergistic effects of improved drinking water and sanitation on childhood stunting $(36,57,58)$. The possible reasons for this variation may be related with initial water 
quality at the source, and with water handling practices during collection, transport and storage at the household level. There is evidence that improved water sources do not correlate well with water that is safe for human consumption $(59,60)$ and that water quality deteriorates from source to point of consumption due to unsafe collection, transport, storage and handling practices $(61,62)$. Thus, further research is required to determine if an improved water source that fulfills the recommended quality standard for consumption, along with safe drinking water handling and storage practices, and the combined effect with improved sanitation, have independent or synergistic effects on child stunting.

The study has strengths. One strength is that this study employed multivariable logistic regression models to control confounding effect and determine the independent effect of irrigation users on child stunting.

\section{Limitations of the study}

The study has limitations. There might be a social desirability bias and a recall bias during answering of questions related to hygienic practices and events happening in the past, such as the child's history of illness and child care practices. Moreover, information on some important confounding variables such as mothers' nutritional status during pregnancy, parasitic infection and the child's birth weight were not collected, and these could also have influenced children's nutritional status. Interpretations of factors associated with child stunting should be with caution since a cause and effect relationship cannot be established using a cross-sectional study design.

\section{Conclusions}

In conclusion, there is a high prevalence of stunting in children from 6-59 months in the study area, with no variation between irrigation and non-irrigation users. Mothers who had no ANC visit, children whose age was between 12 and 47 months, mothers who did not practice hand washing with soap always and children who had fever were the factors associated with higher child stunting. As the government of Ethiopia confront to reduce food insecurity and child stunting through irrigation practices. This study provides insight that irrigation only may not sufficient to improve the nutritional status of children. Therefore, decision makers and program implementers may benefit from the findings of this study to revise strategies and integrate agricultural practice with nutrition education. Strengthening implementation of the government's agricultural practice, combined with interventions to empower women during ANC visit, could accelerate further reductions in child stunting.

\section{Abbreviations}

AOR: Adjusted Odds Ratio; Cl: Confidence Interval; COR: Crude Odds Ratio; SD: Standard Deviations; and WHO: World Health Organization.

\section{Declarations}




\section{Ethics approval and consent to participate}

The study was approved by IRB of College of Medicine and Health Sciences, Bahir Dar University. Permission was obtained after formal support letter submitted to the Amhara Regional Health Bureau, Zonal and Districts Health offices. Information related ethical issue was given for mothers/caretakers by reading its content attached together in the first part of the questionnaire. Each study participant was briefed on the objective of the study, and informed about the right to refuse to participate in the study or to discontinue at any time. Participants were also informed that all data was confidential and personal identifiers were not registered. Interview was conducted after the parents and/or legal guardians of the child participants on their behalf provided verbal consent to participate in the study.

\section{Consent for publication}

Not applicable

\section{Availability of data and materials}

The data set used for final analysis will be available upon corresponding author request

\section{Competing interests}

The authors declare that they have no competing interests.

\section{Funding}

This study did not receive any funding for this work.

\section{Authors' contributions}

BS, MA and MT conceived the study, assisted the data analysis and interpretation, drafted the manuscript and critically reviewed the manuscript. All authors read and approved the final version of the manuscript.

\section{Authors' information}

Balew Sema is working in Bahir Dar University Student Clinic, Bahir Dar, Ethiopia. Muluken Azage and Mulat Tirfie are working at School of Public Health, College of Medicine and Health Sciences, Bahir Dar University, Ethiopia.

\section{Acknowledgments}

The authors would like to acknowledge Bahir Dar University for allowing and approving to do the research project. The authors are highly grateful to the Amhara Regional Health Bureau, Zonal and District Health Offices for their cooperation and support to conduct the study. Finally, the authors would like to acknowledge the study participants, and the data collection team and supervisors for their dedication during data collection. 


\section{References}

1. Micha R, Mannar V, Afshin A, Allemandi L, Baker P, Battersby J, et al. 2020 Global nutrition report: action on equity to end malnutrition. 2020.

2. Leroy JL, Frongillo EA. Perspective: What does stunting really mean? A critical review of the evidence. Advances in Nutrition. 2019;10(2):196-204.

3. Talukder A, Rahman Razu S, Zobayer H. Factors affecting stunting among children under five years of age in Bangladesh. Family Medicine \& Primary Care Review. 2018(4):356-62.

4. Beaton GH. Small but healthy? Are we asking the right question? European journal of clinical nutrition. 1989;43(12):863-75.

5. World Health Organization. Nutrition Landscape Information System (NLIS) country profile indicators: interpretation guide. 2010.

6. Cederholm T, Barazzoni R, Austin P, Ballmer P, Biolo G, Bischoff SC, et al. ESPEN guidelines on definitions and terminology of clinical nutrition. Clinical Nutrition. 2017;36(1):49-64.

7. Geberselassie SB, Abebe SM, Melsew YA, Mutuku SM, Wassie MM. Prevalence of stunting and its associated factors among children 6-59 months of age in Libo-Kemekem district, Northwest Ethiopia; A community based cross sectional study. PloS one. 2018;13(5):e0195361.

8. Rakotomanana H, Gates GE, Hildebrand D, Stoecker BJ. Determinants of stunting in children under 5 years in Madagascar. Maternal \& child nutrition. 2017;13(4):e12409.

9. Ringler SPaMB, affiliations Aa. Evaluating the pathways from small-scale irrigation to dietary diversity: evidence from Ethiopia and Tanzania 2018; Volume 10, I Cite as(Issue 4,): pp 981-97.

10. Woodruff BA, Wirth JP, Bailes A, Matji J, Timmer A, Rohner F. Determinants of stunting reduction in Ethiopia 2000-2011. Maternal \& child nutrition. 2017;13(2):e12307.

11. Delbiso TD, Rodriguez-Llanes JM, Donneau A-F, Speybroeck N, Guha-Sapir D. World Health Assembly». Bulletin of the World Health Organization. 2017;95:94-102.

12. Galasso E, Wagstaff A, Naudeau S, Shekar M. The economic costs of stunting and how to reduce them. Policy Research Note World Bank, Washington, DC. 2016.

13. Ethiopian Public Health Institute (EPHI) [Ethiopia] and ICF. Ethiopia Mini Demographic and Health Survey 2019: Key Indicators. Rockville, Maryland, USA: EPHI and ICF. 2019.

14. Fekadu Y, Mesfin A, Haile D, Stoecker BJ. Factors associated with nutritional status of infants and young children in Somali Region, Ethiopia: a cross-sectional study. BMC Public health. 2015;15(1):846.

15. Abebe Z, Zelalem Anlay D, Biadgo B, Kebede A, Melku T, Enawgaw B, et al. High prevalence of undernutrition among children in Gondar town, Northwest Ethiopia: a community-based crosssectional study. International Journal of Pediatrics. 2017;2017.

16. Mecha Distirct Agriculture office. Annula Report of agricicultural practices in Mecha Distcits, West Goojam Zone, Amhara Region. 2018. 
17. Mecha Distirct Health office. Annual Report of Health services in Mecha Distircts, West Gojjam Zone, Amhara Region. 2018.

18. Veronicah K, Kogi-Makau W, Muroki NM. The role of irrigation on improvement of nutritional status of young children in central Kenya. African Journal of Food, Agriculture, Nutrition and Development. 2007;7(2):1-16.

19. Organization WH. Recommendations for data collection, analysis and reporting on anthropometric indicators in children under 5 years old. 2019.

20. Central Statistical Agency [Ethiopia]. Ethiopia Mini Demographic and Health Survey. 2014.

21. Motbainor A, Worku A, Kumie A. Stunting Is Associated with Food Diversity while Wasting with Food Insecurity among Underfive Children in East and West Gojjam Zones of Amhara Region, Ethiopia. PLoS One. 2015;10(8):e0133542.

22. Beka T, Wambui K, Zewditu G, Girum T. Magnitude and Determinants of Stunting in Children Underfive Years of Age in Food Surplus Region of Ethiopia: The Case of West Gojam Zone. . Ethiop J Health Dev. 2009;23(2):98-106.

23. Abebe Z, Haki GD, Baye K. Health Extension Workers' Knowledge and Knowledge-Sharing Effectiveness of Optimal Infant and Young Child Feeding Are Associated With Mothers' Knowledge and Child Stunting in Rural Ethiopia. Food and nutrition bulletin. 2016.

24. Mercedes d, Monika B. WHO Global Database on Child Growth and Malnutrition World Health Organization/Department of Nutrition for Health and Development CH - 1211 Geneva 27. Avilable at http://www.who.int/nutgrowthdb/about/introduction/en/index5.html. Acess date April 16, 2016. 1997.

25. Hagos S, Lunde T, Mariam DH, Woldehanna T, Lindtjorn B. Climate change, crop production and child under nutrition in Ethiopia; a longitudinal panel study. BMC Public Health. 2014;14:884.

26. Ali D, Saha K, Nguyen P, Diressie M, Ruel M, Menon P. Household food insecurity is associated with higher child undernutrition in Bangladesh, Ethiopia, and Vietnam, but the effect is not mediated by child dietary diversity. J Nutr. 2013;143(12):2015-21.

27. Lutter CK, Daelmans BM, de Onis M, Kothari MT, Ruel MT, Arimond M, et al. Undernutrition, poor feeding practices, and low coverage of key nutrition interventions. Pediatrics. 2011;128(6):e1418-27.

28. Benson T. Association between irrigated farming and improved nutrition in farm households in Malawi. Agrekon. 2015;54(3):62-86.

29. Passarelli S, Mekonnen D, Bryan E, Ringler C. Evaluating the pathways from small-scale irrigation to dietary diversity: evidence from Ethiopia and Tanzania. Food Security. 2018;10(4):981-97.

30. Ghattas H. Food Security and Nutrition in the context of the Global Nutrition Transition. Food and Agriculture Organization: Rome, Italy. 2014.

31. FAO. Synthesis of Guiding Principles on Agriculture Programming for Nutrition. 2013.

32. Das PK, Bhavani R, Swaminathan M. A farming system model to leverage agriculture for nutritional outcomes. Agricultural Research. 2014;3(3):193-203. 
33. Oluwole $\mathrm{S}$, Adeola $\mathrm{O}$. Prevalence of food insecurity among rural communities and its effects on nutritional status of children (8-15 years) in Ondo State, Nigeria. Journal of medicine and medical sciences. 2012;3(1):005-15.

34. Nkonya E, lannotti L, Sakwa B, Wielgosz B, Gandhi V, Kato E, et al. Baseline study of KickStart treadle pumps in East Africa. Unpublished, International Food Policy Research Institute, Washington, DC. 2011.

35. Kwami CS, Godfrey S, Gavilan H, Lakhanpaul M, Parikh P. Water, Sanitation, and Hygiene: Linkages with Stunting in Rural Ethiopia. Int J Environ Res Public Health. 2019;16(20):3793.

36. Haile D, Azage M, Mola T, Rainey R. Exploring spatial variations and factors associated with childhood stunting in Ethiopia: spatial and multilevel analysis. BMC pediatrics. 2016;16(1):49.

37. Lin A, Arnold BF, Afreen S, Goto R, Huda TM, Haque R, et al. Household environmental conditions are associated with enteropathy and impaired growth in rural Bangladesh. The American journal of tropical medicine and hygiene. 2013;89(1):130-7.

38. Titaley CR, Ariawan I, Hapsari D, Muasyaroh A, Dibley MJ. Determinants of the Stunting of Children Under Two Years Old in Indonesia: A Multilevel Analysis of the 2013 Indonesia Basic Health Survey. Nutrients. 2019;11(5):1106.

39. Hamel C, Enne J, Omer K, Ayara N, Yarima Y, Cockcroft A, et al. Childhood Malnutrition is Associated with Maternal Care During Pregnancy and Childbirth: A Cross-Sectional Study in Bauchi and Cross River States, Nigeria. Journal of public health research. 2015;4(1):408.

40. Mushtaq MU, Gull S, Khurshid U, Shahid U, Shad MA, Siddiqui AM. Prevalence and sociodemographic correlates of stunting and thinness among Pakistani primary school children. BMC Public Health. 2011;11.

41. Bloss E, Wainaina F, Bailey RC. Prevalence and Predictors of Underweight, Stunting, and Wasting among Children Aged 5 and Under in Western Kenya. J Trop Pediatr. 2004;50.

42. Haile D, Azage M, Mola T, Rainey R. Exploring spatial variations and factors associated with childhood stunting in Ethiopia: spatial and multilevel analysis. BMC Pediatr. 2016;16(1):1-14.

43. Adekanmbi VT, Kayode GA, Uthman OA. Individual and contextual factors associated with childhood stunting in Nigeria: a multilevel analysis. Matern Child Nutr. 2013;9.

44. Wamani H, Astrom AN, Peterson S, Tumwine JK, Tylleskar T. Boys are more stunted than girls in subSaharan Africa: a meta-analysis of 16 demographic and health surveys. BMC Pediatr. 2007;7.

45. Keino S, Plasqui G, Ettyang G, Borne B. Determinants of stunting and overweight among young children and adolescents in sub-Saharan Africa. Food and nutrition bulletin. 2014;35.

46. Alemayehu M, Tinsae F, Haileslassie K, Seid O, Gebregziabher G, Yebyo H. Undernutrition status and associated factors in under-5 children, in Tigray, Northern Ethiopia. Nutrition (Burbank, Los Angeles County, Calif). 2015;31(7-8):964-70.

47. Gera T, Shah D, Sachdev HS. Impact of Water, Sanitation and Hygiene Interventions on Growth, Nondiarrheal Morbidity and Mortality in Children Residing in Low- and Middle-income Countries: A Systematic Review. Indian pediatrics. 2018;55(5):381-93. 
48. Saxton J, Rath S, Nair N, Gope R, Mahapatra R, Tripathy P, et al. Handwashing, sanitation and family planning practices are the strongest underlying determinants of child stunting in rural indigenous communities of Jharkhand and Odisha, Eastern India: a cross-sectional study. Maternal \& child nutrition. 2016;12(4):869-84.

49. Ngure FM, Reid BM, Humphrey JH, Mbuya MN, Pelto G, Stoltzfus RJ. Water, sanitation, and hygiene (WASH), environmental enteropathy, nutrition, and early child development: making the links. Annals of the New York Academy of Sciences. 2014;1308:118-28.

50. Mbuya MN, Humphrey JH. Preventing environmental enteric dysfunction through improved water, sanitation and hygiene: an opportunity for stunting reduction in developing countries. Matern Child Nutr. 2015.

51. Merchant AT, Jones C, Kiure A, Kupka R, Fitzmaurice G, Herrera MG, et al. Water and sanitation associated with improved child growth. European journal of clinical nutrition. 2003;57(12):1562-8.

52. Bain R, Wright J, Yang H, Pedley S, Gundry S, Bartram J. Improved but not necessarily safe: water access and the Millennium Development Goals [GWF Discussion Paper 1225]. Canberra: Global Water Forum; 2012. Available from:http://www.globalwaterforum.org/wpcontent/uploads/2012/07/Improved-but-not-necessarily-safe_Water-access-and-the-MillenniumDevelopment-Goals_GWF1225.pdf [accessed 21 April 2016]. 2012.

53. Godfrey S, Labhasetwar P, Wate S, Pimpalkar S. How safe are the global water coverage figures? Case study from Madhya Pradesh, India. Environ Monit Assess. 2011;176:561-74.

54. Rah JH, Cronin AA, Badgaiyan B, Aguayo VM, Coates S, Ahmed S. Household sanitation and personal hygiene practices are associated with child stunting in rural India: a cross-sectional analysis of surveys. BMJ open. 2015;5(2):e005180.

55. Dearden KA, Schott W, Crookston BT, Humphries DL, Penny ME, Behrman JR, et al. Children with access to improved sanitation but not improved water are at lower risk of stunting compared to children without access: a cohort study in Ethiopia, India, Peru, and Vietnam. BMC Public Health. 2017;17(1):110.

56. Fink G, Gunther I, Hill K. The effect of water and sanitation on child health: evidence from the demographic and health surveys 1986-2007. International journal of epidemiology. 2011;40(5):1196204.

57. Rah JH, Sukotjo S, Badgaiyan N, Cronin AA, Torlesse H. Improved sanitation is associated with reduced child stunting amongst Indonesian children under 3 years of age. Maternal \& Child Nutrition. 2020;n/a(n/a):e12741.

58. Bekele T, Rawstorne P, Rahman B. Effect of water, sanitation and hygiene interventions alone and combined with nutrition on child growth in low and middle income countries: a systematic review and meta-analysis. BMJ open. 2020;10(7):e034812.

59. Shaheed A, Orgill J, Montgomery MA, Jeuland MA, Brown J. Why "improved" water sources are not always safe. Bull World Health Organ. 2014;92(4):283-9. 
60. Baum R, Kayser G, Stauber C, Sobsey M. Assessing the microbial quality of improved drinking water sources: results from the Dominican Republic. The American journal of tropical medicine and hygiene. 2014;90(1):121-3.

61. Shaheed A, Orgill J, Ratana C, Montgomery MA, Jeuland MA, Brown J. Water quality risks of 'improved' water sources: evidence from Cambodia. Tropical medicine \& international health : TM \& IH. 2014;19(2):186-94.

62. Holman EJ, Brown J. Safety of packaged water distribution limited by household recontamination in rural Cambodia. Journal of water and health. 2014;12(2):343-7.

\section{Supplementary Files}

This is a list of supplementary files associated with this preprint. Click to download.

- Supplementfile1.docx 